\title{
一眼レフカメラ内部ミラーモデルの衝突時挙動と跳ね返り量* （回転支持された長方形平板の衝突時挙動の測定）
}

松本 大樹*1, 平島 正樹 ${ }^{* 2}$

\section{Vibration Behavior and Rebound Angle on the Collision of Mirror Models inside a SLR Camera (Measurement of Collision Behavior of Rotary Support Rectangular Plates)}

\author{
Hiroki MATSUMOTO ${ }^{* 1}$ and Masaki HIRASHIMA \\ ${ }^{* 1}$ Muroran Institute of Technology \\ 27-1 Mizumoto-cho, Muroran, Hokkaido, 050-8585 Japan
}

\begin{abstract}
This study deals with the rebound vibration characteristics of a SLR camera's internal mirror model. The mechanism of the mirror rebound phenomena is considered by using six types of rectangle metal plate models. In the experiment, the behavior of vibration during the rebound phenomena is observed. The mirror models are supported with rotational axis at long axis of the model. The mirror models swing down freely from the horizontal plane and then hit with a stopper. Amount of rebound is measured by a laser displacement meter. The results indicate that the rebound amount depends on the stopper position. The vibration behavior after the collision varies by stopper position. The vibration after the collision depends on the deformation while in contact with the stopper at the time of collision. We observed that when the amount of rebound is small, there is a tendency that the vibration after the collision becomes large.
\end{abstract}

Key Words : Vibration of Mechanism, Vibration of Continuous System, Kinematic, Nonlinear Vibration

\section{1. 緒言及び目的}

一眼レフカメラは，ファインダーで撮影対象の実像を確認しながら撮影寸ることができるカメラである．その ために一眼レフカメラのボディ内には, ミラーおよびペンタプリズムなどの部品が備わっている. カメラレンズ を透過した光は，カメラ内部で斜めに設置されたミラーに到達する．ミラーは一部分がハーフミラーとなってお り, 到達した光は, ファインダー方向とボディ下部に設置されたオートフォーカス素子の上下二方向に分離され る.この状態でファインダーをのぞきながらピントを合わせることができ，ピントを合わせた後，レリーズボタ ンを押寸とミラーは持ち上がり，光は撮像素子またはフィルムの感光面に記録される．その瞬間はファインダー の光は遮られ，撮影が終わるとミラーは元の位置に戻り，ファインダーに像が戻る. ミラーの動作は高速に行わ れるが，ミラーは回転軸を中心に回転して持ち上げられ，もとの位置に戻る際に，位置決め用のストッパーに衝 突する. 連続撮影の際には，この動作を繰り返すことになる.

しかし，ストッパーとの衝突によりミラーが跳ね返ると，ミラーが静止するまでオートフォーカス素子を働か せることができず，連写速度が減少してしまう問題が出てくる．この対策のために，高級機種では跳ね返り抑制 の機構を用いて跳対返りを抑制しているものの，コストがかかることになる．このコストを抑え，跳㸚返りを抑 制するためには, ストッパーの位置やミラーの形状などを変えることでミラーの跳ね返りを抑制する必要がある.

* 原稿受付 2012 年 10 月 21 日

${ }^{* 1}$ 正員, 室蘭工業大学 ( $\bar{T} 050-8585$ 北海道室蘭市水元町 27-1)

*2 学生員, 室蘭工業大学 大学院

E-mail: h_matsu@mmm.muroran-it.ac.jp 
平板に模擬される物体との衝突跳悋返りの現象を対象とする研究としては，テニスラケットやバットとボール との衝突に関する研究があり, 主に固有值, 固有モードによる検討や, 力学的エネルギからの検討から跳ね返り の大きさについて検討している(1) (6). 本研究におけるミラー挙動の場合においても，ミラーモデルの跳ね返り量 とミラーモデルの振動挙動に関連があることは，テニスラケット等の研究から容易に想像できるが，ミラーモデ ルの場合には跳ね返る物体に着目して現象を説明する必要がある。このように衝突後に跳ね返る平板の剛体挙動 と弾性挙動に着目した研究例は筆者らの知る限り見られない. また, 衝突対象の時刻歴挙動についても明らかに している例は見られないことから，本研究では，衝突跳ね返り現象の理解を深めるために，跳ね返る対象自身の 跳ね返り量と振動挙動の計測が必要と考えた.

そこで本研究は，ミラーの跳㸚返り現象の本質的なメカニズムを明らかにする基礎的実験として，実機のミラ 一を単純化したミラーモデルを作製し，ミラーの跳ね返り量とストッパー位置との関連，ストッパー衝突時のミ ラーモデルの挙動を調べ，現象をとらえることを目的とする．実機のミラーは，ミラー面を支える支持筐体やミ ラー，サブミラーなど複数の部品からなるが，本研究ではごく単純な長方形平板にモデル化している．跳ね返る 大きさはさまざまな因子が絡むと考えられるが，本報告では，平板とストッパー位置との関連に着目し，ストッ パーの位置の違いによる跳ね返り量の変化を明らかにする.さらに，ミラーモデルの形状を変え，その影響から 跳㸚返りのメカニズムを考察する，その際には，ミラーの衝突の瞬間の振動挙動を計測し，どのような現象が起 きているかを明らかにすることで，跳ね返り量が変化する理由を考察する.

\section{2. 実験装置及び実験方法}

\section{$2 \cdot 1$ ミラーモデル}

図 1 に実験に使用するミラーモデルを示す．ミラーモデルとストッパーは全てアルミニウム製で，ボルトおよ び軸はステンレス製である.

ミラーモデルは全て厚さ $1 \mathrm{~mm}$ である. 大きさは $80 \times 60 \times 1 \mathrm{~mm}$ の Mirror model (a)を基本形状としている.治具， ボルト，ベアリング，軸は全てのミラーモデルに共通であり，測定を行う際はミラーモデルのみを取り替える. ミラーモデルは M3 のボルトを締めつけて治具に固定される．また，軸と治具は一体で回転し，実験装置本体に ベアリングで支えられ回転運動ができるようになっている．ここでは，現象をより詳細に計測するために，実機 よりも拡大したモデルを用いる．実機との違いを検討するために，予備的な実験として，実機とほぼ同じ大きさ の簡易モデルを用いてその跳ね返り量を計測し，Mirror model (a) と比較した．その結果を図 2 に示す．実機の簡 易モデルは $30 \times 40 \times 1 \mathrm{~mm}$ のモデルで, 回転軸であるピンを受ける穴部分は平板部分を折り曲げて製作している. ストッパー位置は $x$ 及び $y$ 軸方向の 2 方向に移動させて計測した. 図 2 より, 跳ね返り量が最小を示すストッパ 一の位置は，Mirror model (a) と簡易モデルとでほぼ同じとなっていることや，ストッパー位置が $x, y$ 軸方向とで 跳返り量の変化の傾向がほぼ同じであることがわかり，実機を拡大した Mirror model (a)においても特性を評価 できることが確認できる. なお，本研究では実機の構造上の制約から，ストッパー位置は $y$ 軸方向のみに設置さ れる場合に限定して検討寸る. Mirror model (b)は中心に $40 \times 20 \mathrm{~mm}$ の穴があいている.これは，実機のミラーの 支持筐体の中心部にオートフォーカス素子へ透過させるための穴があいているため, このような形状をとった.

Mirror model (c)〜(f)には $4 \mathrm{~mm}$ のスリットが入っており, スリットの有無で衝突時どのような変化が現れるか調べ るために設けている.

図 3 に跳ね返り量測定時のストッパー位置を示寸．ストッパーは図に Stopper と示してあるミラーモデル右端 を原点とし，y軸方向へ $0 \mathrm{~mm}$ から $42 \mathrm{~mm}$ までを $2 \mathrm{~mm}$ 間隔で移動させ，各ストッパー位置 $y_{s}$ での跳ね返り量を測 定する．ストッパー位置は Mirror model (a)〜 f f)まで同様である. ストッパーモデルは先端が $\phi 5 \mathrm{~mm}$ の円柱とな っており，ミラーモデルと先端から $1 \mathrm{~mm}$ だけ接触する位置にある. 


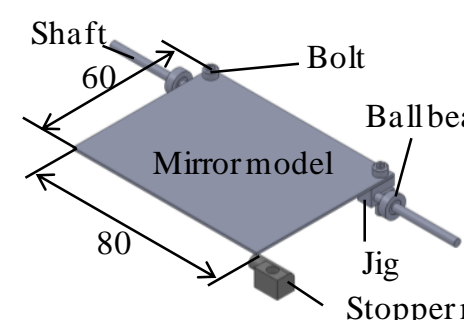

Mirror model(a)

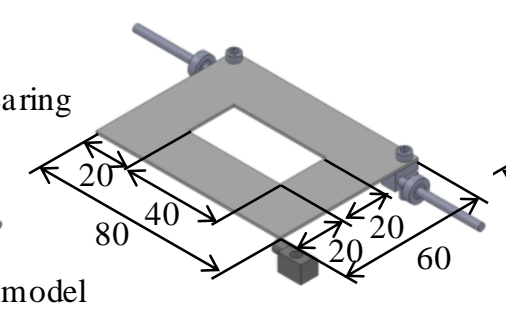

Mirror model(b)

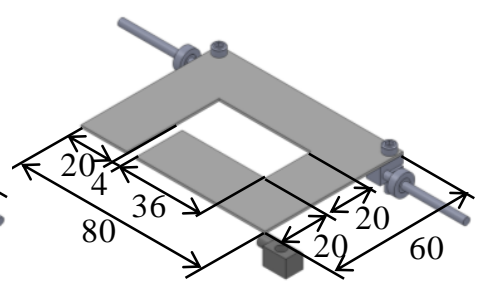

Mirror model(c)

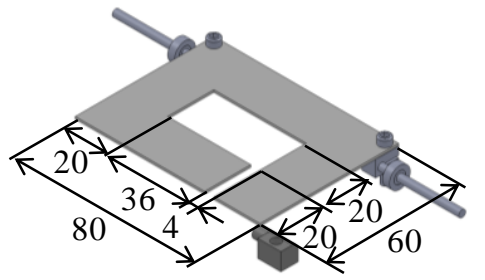

Mirror model(d)

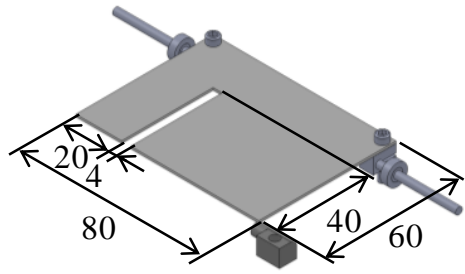

Mirror model(e)

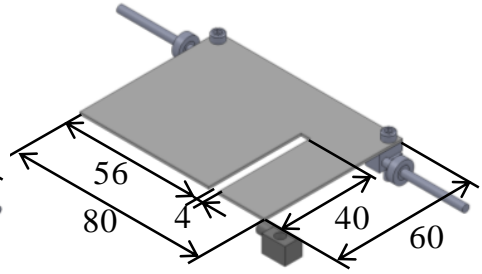

Mirrormodel(f)

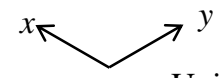

Unit $[\mathrm{mm}]$

Fig.1 Mirror model
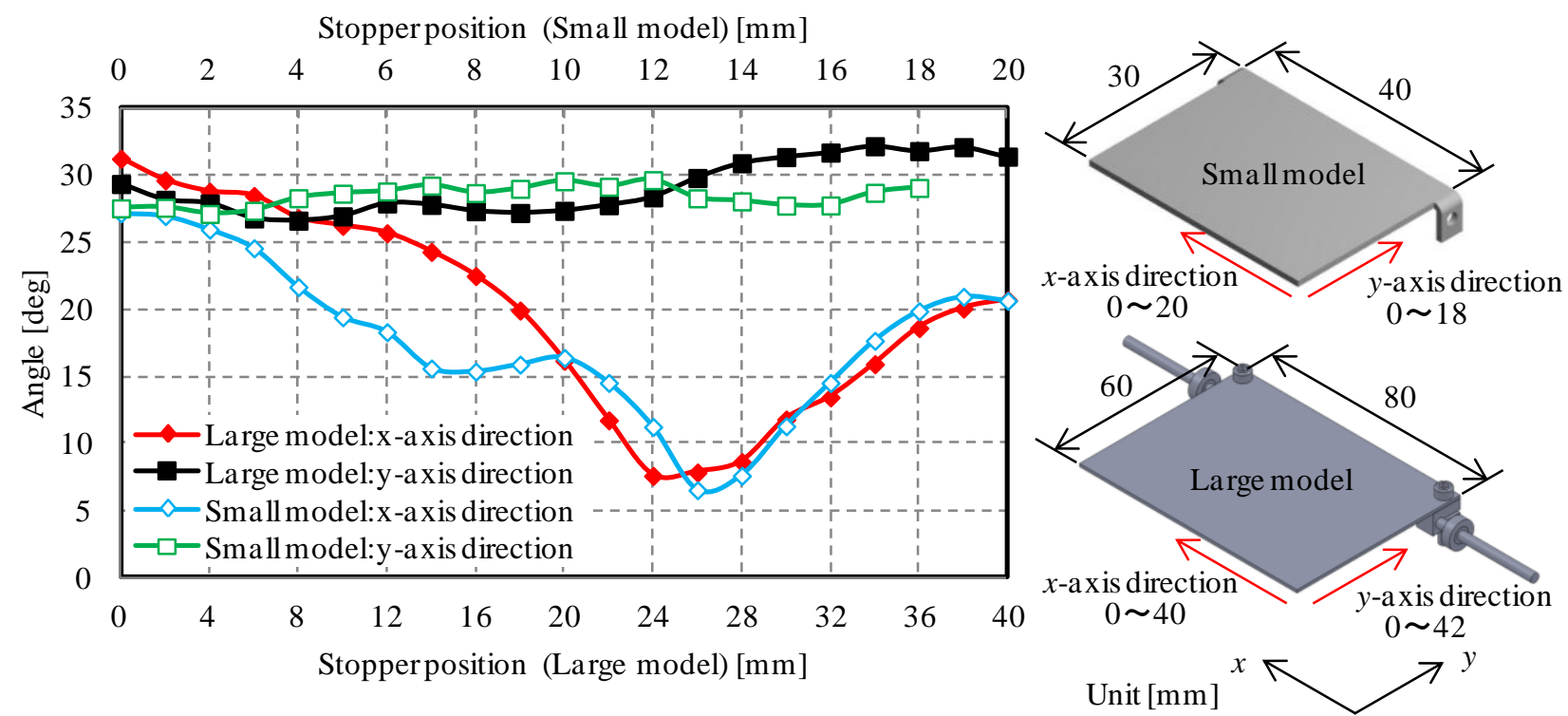

Fig.2 Preliminary experimental result

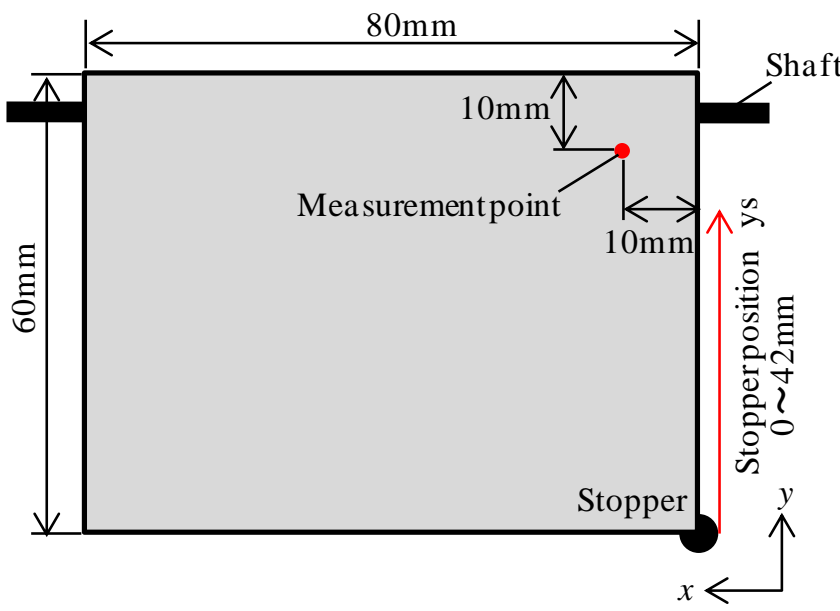

Fig.3 Stopper position and Measurement point 


\section{$2 \cdot 2$ 跳ね返り量測定 ${ }^{(7)}$}

ストッパー位置による跳ね返り量の変化を明らかにするために跳ね返り量測定を行う. 図 4 に実験装置概略図 を示す．ストッパーは水平から $45 \mathrm{deg}$ 下方に設置し，水平な位置からミラーモデルを自由落下させる．レーザ変 位計による測定点は図 3 および図 5 に示すように，ミラーモデル上辺および右辺よりそれぞれ $10 \mathrm{~mm}$ の地点とし た.この時のミラーモデルの跳ね返り量をレーザ変位計で測定し, A/D コンバータを介してパソコンに取り込む. 各ストッパー位置において 5 回ずつ測定し角度に変換する. 跳ね返り量は, 最初にミラーモデルとストッパーが 衝突してからの最大值とする. 跳ね返り量は 5 回の平均值とする. 跳㸚返り量は $\theta_{r}[\mathrm{deg}]$ とする. 5 回の跳㸚返り 量計測のばらつきは最大 0.9 度，平均 0.4 度程度で，充分な再現性を有していることを確認している.

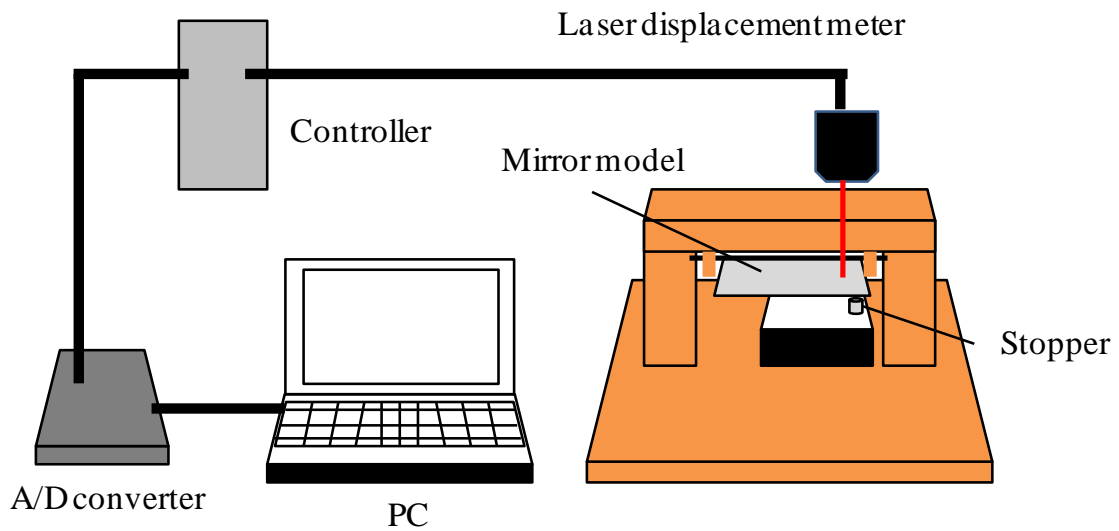

Fig.4 Schematic diagram of experimental equipment

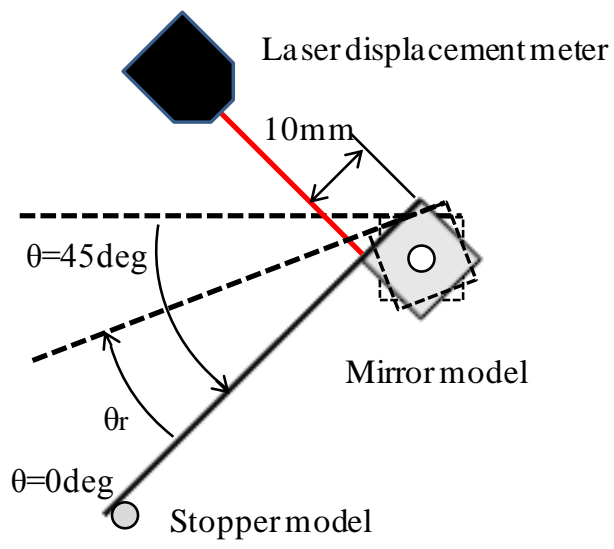

Fig.5 Measuring the amount of rebound

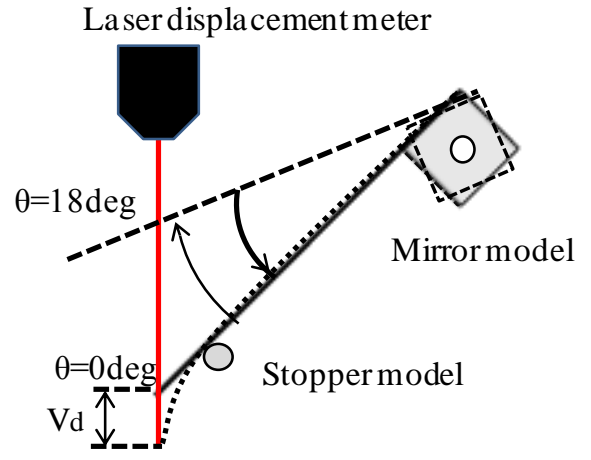

Fig.6 Measuring vibration behaviour

\section{$2 \cdot 3$ 跳ね返り量への変換}

跳ね返り量の計測は，レーザ変位計により垂直方向変位の計測により評価するが，ミラーモデルは回転運動を 行うため，測定位置により結果が変化し同じ結果が得られない，そこでレーザ変位計で測定した值を幾何学的な 関係を用いて跳㸚返り角に換算し，それを跳衫返り量として評価する. レーザ変位計で得られた垂直方向変位 $x$ を跳ね返り角 $\theta$ に変換する方法を以下に記す. 図 7 より $\theta=\angle C B D=\angle B O A, \angle C D B=\angle B A O=90[\mathrm{deg}]$ であるので三 角形の定理より， $\triangle C B D$ と $\triangle B O A$ は相似であることがわかる。 $\triangle O A B$ にいてみると式（1）が得られる.

$$
B O=\frac{a}{\cos \theta}
$$

また，式（1）を考慮に入れ $\triangle B C D$ にいてみると式（2）が得られる. 


$$
\tan \theta=\frac{C D}{B D}=\frac{x-D E}{b}=\frac{x-B F}{b}=\frac{x-(B O-a)}{b}=\frac{x-\left(\frac{a}{\cos \theta}-a\right)}{b}=\frac{\sin \theta}{\cos \theta}
$$

式（2）を整理し三角関数の合成を行うと式（3）が得られる.

$$
\sqrt{b^{2}+(x+a)^{2}} \sin (\theta+\phi)=-a
$$

ここで

$$
\sin \phi=\frac{-(x+a)}{\sqrt{b^{2}+(x+a)^{2}}}
$$

式（3）を変形し，式（4）を代入すると式（5）が得られる.

$$
\theta=\sin ^{-1}\left(\frac{-a}{\sqrt{b^{2}+(x+a)^{2}}}\right)-\phi=\sin ^{-1}\left(\frac{-a}{\sqrt{b^{2}+(x+a)^{2}}}\right)-\sin ^{-1}\left(\frac{-(x+a)}{\sqrt{b^{2}+(x+a)^{2}}}\right)
$$

式 $(5)$ によって跳ね返り角を求める. ここで $a$ はミラーモデルの設計值, $b$ はレーザ変位計の照射位置によって 決まる值である.

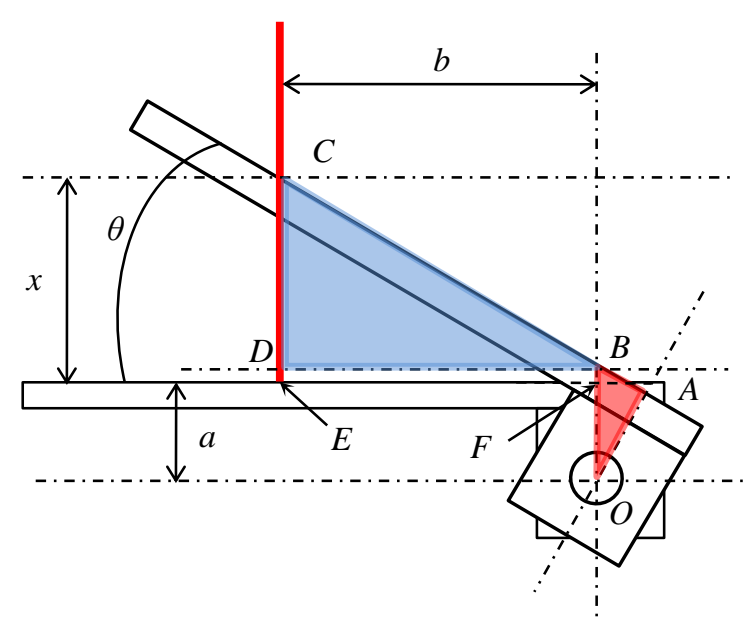

Fig.7 Conversion of displacement into angle

\section{$2 \cdot 4$ ストッパー衝突時挙動測定 ${ }^{(7)}$}

ミラーモデルとストッパーとが衝突する瞬間に，どのような挙動を示すかを観測することで，跳ね返りのメカ ニズムを検討する，そのために，レーザ変位計で衝突前後のミラーモデルの変形などを測定する.

実験装置は図 4 に示寸跳衫返り量測定と同様の実験装置を用いる。レーザ変位計の計測範囲の制限のため，跳 ね返り量計測と異なる高さから落下させ，その際のミラーモデルの挙動を計測する. 図 6 に側面図を示す，ス卜 ッパーは水平から 45deg 下方に設置する. ミラーモデルとストッパーが接触した静的位置を $0 \mathrm{deg}$ とし, そこから $18 \mathrm{deg}$ 上方からミラーモデルを自由落下させ, 先端の数力所の垂直方向変位を測定する. ミラーモデルとストッ パーが衝突したときの垂直方向変位を $V_{d}$ とする. ストッパーは図 3 で Stopper と示してあるミラーモデル右端を 原点とし， $y$ 軸方向に $0 \mathrm{~mm}$ から $40 \mathrm{~mm}$ まで $4 \mathrm{~mm}$ 間隔で移動させ各ストッパー位置で測定する．また，跳ね返り 量測定結果から最大・最小の跳ね返り量となったストッパー位置でも測定する．各ストッパー位置ではそれぞれ 3 回ずつ測定を行い, 再現性を確認している.ばらつきはほぼ無く, 安定した結果が得られている. 図 8 にミラ 一モデル面上の測定点を示す. Mirror model (a) と Mirror model (b)はミラーモデル両端とミラーモデルの中間を含 めた 3 点で測定を行い，ストッパーのある右側から順に測定点 1，2，3 とする. Mirror model (c) ( f)はミラーモ デルの端で測定を行い，右側から順に測定点 1，2，3，4 とする. 


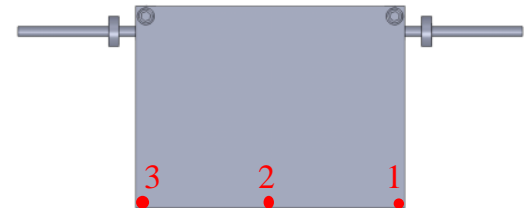

Mirror model(a)

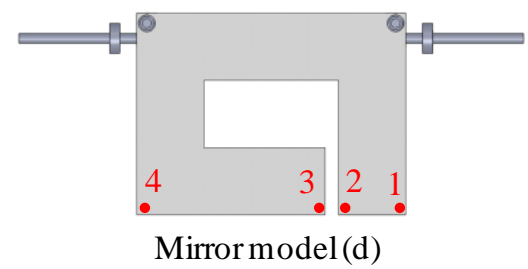

Mirror model(d)

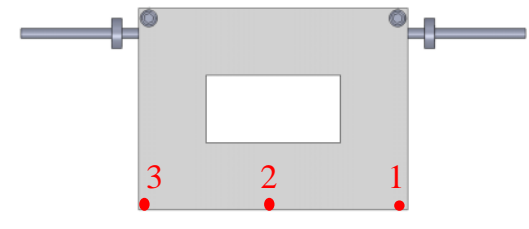

Mirror model(b)

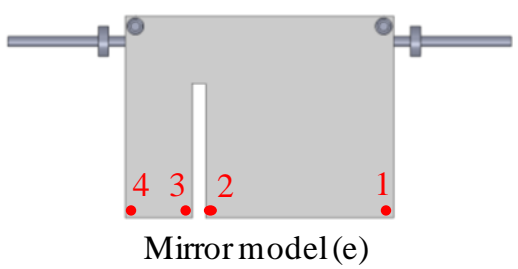

Mirror model(e)

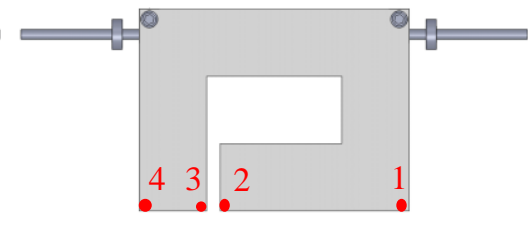

Mirror model(c)

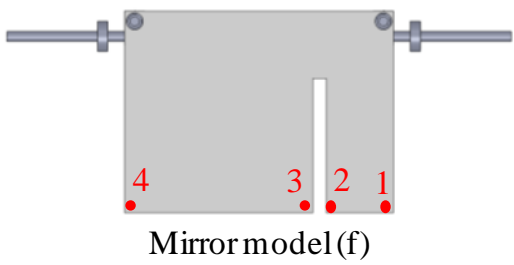

: Mea surement point

Fig.8 Measurement point

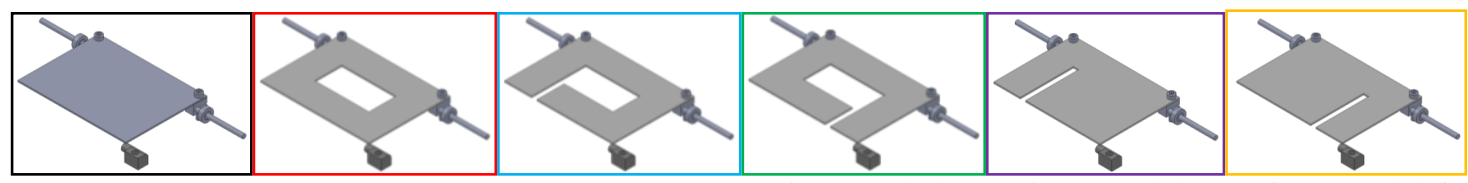

Mirrormodel(a) Mirror model(b) Mirrormodel(c) Mirrormodel(d) Mirrormodel(e) Mirrormodel(f)

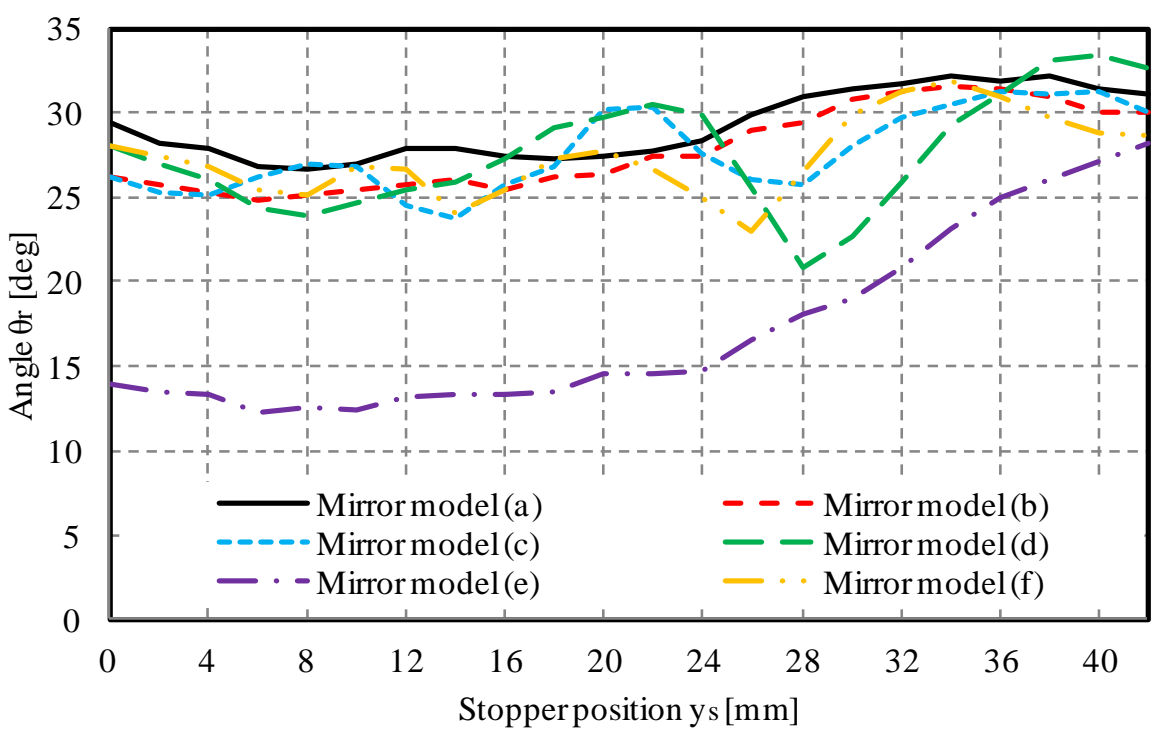

Fig.9 Rebound angle

\section{$3 \cdot 1$ 跳ね返り量測定結果}

\section{3. 実験結果}

図 9 に跳ね返り量測定結果を示す。いずれのミラーモデルにおいても，跳ね返り量はストッパーとの位置関係 で変動がみられることがわかる。

まず基本形状とした Mirror model (a)は, ストッパー位置 $y_{s}=34 \mathrm{~mm}$ で最大の跳ね返りとなり，跳ね返り量 $\theta_{r}$ は約 $32 \mathrm{deg}$ であった。 また $y_{s}=8 \mathrm{~mm}$ で最小の跳ね返りとなり， $\theta_{r}$ は約 $27 \mathrm{deg}$ であった。最大值と最小值の差は約 $6 \mathrm{deg}$ であり，各ストッパー位置に対する跳㸚返り量の変化をみると，他と比較して，全体的に緩やかな変化をしてい ることがわかる.

中央に穴のある Mirror model (b)は， $y_{s}=34 \mathrm{~mm}$ で最大の跳ね返りとなり， $\theta_{r}$ は約 $32 \mathrm{deg}$ であった．また $y_{s}=6 \mathrm{~mm}$ で最小の跳衩返りとなり， $\theta_{r}$ は約 $25 \mathrm{deg}$ であった．最大值と最小值の差は約 $7 \mathrm{deg}$ であり，ストッパー位置に対す 
る跳ね返り量の変化の傾向も Mirror model (a)と近い結果となった.このことから中央部の穴は，跳ね返りにはほ ぼ影響を及ぼさないと考えられる。

さらにスリットを有する Mirror model (c)は $y_{s}=36 \mathrm{~mm}$ で最大の跳ね返りとなり， $\theta_{r}$ は約 $31 \mathrm{deg}$ であった．また $y_{s}=14 \mathrm{~mm}$ で最小の跳ね返りとなり， $\theta_{r}$ は約 $24 \mathrm{deg}$ であった．最大值と最小值の差は約 $8 \mathrm{deg}$ であった．ストッパー 位置に対する跳数返り量の変化は Mirror model (a)，(b)とは異なる． $y_{s}$ が大きくなり，ストッパー位置が軸側に近 づくにつれ，跳坟返り量が上下し，ストッパー位置に依存して大きく変動することが明らかとなった.

Mirror model (d)は， $y_{s}=40 \mathrm{~mm}$ で最大の跳ね返りとなり， $\theta_{r}$ は約 $33 \mathrm{deg}$ であった．また $y_{s}=28 \mathrm{~mm}$ で最小の跳ね返 りとなり， $\theta_{r}$ は約 $21 \mathrm{deg}$ であった．最大值と最小值の差は約 $13 \mathrm{deg}$ であったが， $y_{s}=28 \mathrm{~mm}$ のとき極端に跳ね返り 量が小さくなった．また，スリットの入っている位置が異なる Mirror model (c) とは，質量は同じで，軸まわりの 慣性モーメントも同一だが，ストッパー位置に対する跳ね返り量の変化は異なることがわかる.

穴が無く, スリットのみがある Mirror model (e)は, $y_{s}=42 \mathrm{~mm}$ で最大の跳ね返りとなり， $\theta_{r}$ は約 $28 \mathrm{deg}$ であった. また $y_{s}=6 \mathrm{~mm}$ で最小の跳ね返りとなり， $\theta_{r}$ は全ミラーモデル中で最小の約 $12 \mathrm{deg}$ であった. 最大值と最小值の差 は約 16deg であり，全体の跳ね返り量の傾向は $y_{s}$ が上がるにつれ跳ね返り量が大きくなる傾向がある．これは， スリットを境とし，ストッパーがない側の部分が，ストッパー側の挙動を抑制するような効果を果たしていると 考えられる.

最後に, Mirror model(f)は， $y_{s}=34 \mathrm{~mm}$ で最大の跳ね返りとなり， $\theta_{r}$ は約 $32 \mathrm{deg}$ であった．また $y_{s}=26 \mathrm{~mm}$ で最小 の跳㸚返りとなり， $\theta_{r}$ は約 $23 \mathrm{deg}$ であった．最大值と最小值の差は約 $9 \mathrm{deg}$ であり，全体の跳ね返り量の傾向は $y_{s}$ が上がるにつれ跳ね返り量が上下し, model(c)〜(d) と似た傾向となっていて, 同じ慣性モーメントを持つ Mirror model(e)とは大きく異なる.

これらのことから，同一の慣性モーメントを持っていても，スリットとストッパーとの位置関係が異なること で，跳ね返り量はかなり大きく変化することがわかった。このことから, 衝突時に起こる振動挙動等, 衝突時の 動的な挙動の違いによって跳㸚返り量が変化していることがわかる.

\section{$3 \cdot 2$ ストッパー衝突時挙動測定結果}

衝突時の挙動の違いを検討する. 図 10 (a), （b）に $y_{s}=8 \mathrm{~mm}$ と $y_{s}=34 \mathrm{~mm}$ のときの Mirror mode1 (a)の衝突 時の挙動測定結果を示す. $V_{d}=0 \mathrm{~mm}$ が静的な状態でのミラーモデルの位置を示している. 最小の跳ね返りを 示した $y_{s}=8 \mathrm{~mm}$ のときのグラフでは, $V_{d}=0 \mathrm{~mm}$ でミラーモデルがストッパーと衝突し，その後，測定点 2,3 は負の值を示していることから, 衝突による弾性変形で, 静位置よりも下方に移動していることがわかる. すなわち，衝突によってミラーモデルは変形していることがわかる．それに反して，測定点 1 ではストッパ 一に近いため変形量はほぼ 0 であることがわかる。これらのことから, 衝突時にミラーモデルは測定点 3

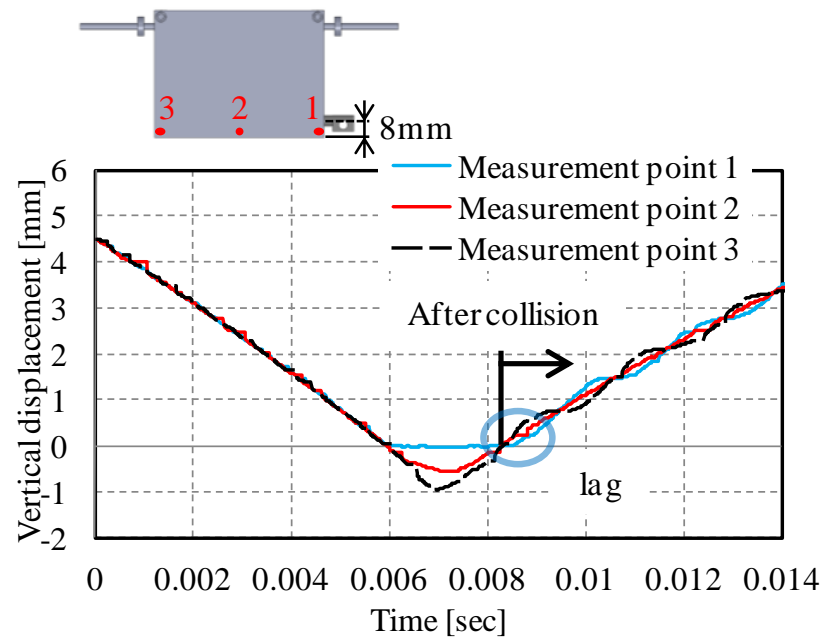

(a) Stopper position: $y_{s}=8 \mathrm{~mm}\left(\theta_{r}=27 \mathrm{deg}\right)$
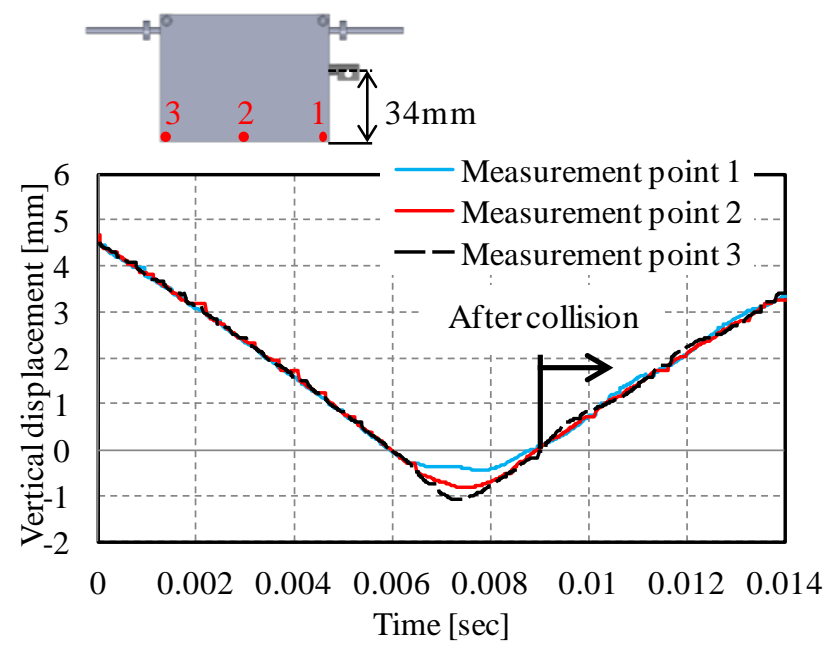

(b) Stopper position: $y_{s}=34 \mathrm{~mm}\left(\theta_{r}=32 \mathrm{deg}\right)$

Fig.10 Measurement result of the vibration behavior of Mirror model (a) 
側が沈み込むように変形していることがわかる. 全ての測定点で $V_{d}>\mathrm{mm}$ となる瞬間を跳ね返る瞬間と考え， 跳ね返り後の各点の挙動をみると，測定点 $1 ， 3$ は逆位相の振動をしていることがわかる. この挙動を最大 の跳ね返りを示した $y_{s}=34 \mathrm{~mm}$ の場合と比べると, 最小の跳ね返りのモデル $\left(y_{s}=8 \mathrm{~mm}\right)$ のほうが振幅は大きい ことがわかる．さらに $V_{d}=0 \mathrm{~mm}$ を通過する時間をみると，ストッパー側にある測定点 1 が他の測定点より遅 れてストッパーから離れていることがわかる. この結果, ミラーモデルの両端の位相がずれるために, 先端

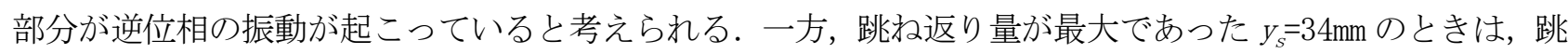
ね返り後はほぼ振動していないことがわかる.

次に，図 $11(\mathrm{a}), \quad(\mathrm{b})$ に $y_{s}=6 \mathrm{~mm}$ と $y_{s}=34 \mathrm{~mm}$ のときの Mirror model (b)の測定結果を示寸． $y_{s}=6 \mathrm{~mm}$ は最小の跳 放返りを示しており， $y_{s}=34 \mathrm{~mm}$ のとき最大の跳衫返りを示している. 図 11 (a)，(b) より Mirror model (b)は Mirror model (a)とほぼ同じ挙動を示していることがわかる. 跳䘤返り量の測定結果と同様に, 中央の穴は衝突後の振動 にも大きな影響が無いことがわかった。

図 12 (a) 〜 (d) に $y_{s}=14 \mathrm{~mm}, 20 \mathrm{~mm}, 28 \mathrm{~mm} ， 36 \mathrm{~mm}$ のときの Mirror model (c)の挙動測定結果を示す. 跳妏返 り量が小さくなった $y_{s}=14 \mathrm{~mm}$ と $y_{s}=28 \mathrm{~mm}$ では, 跳ね返り後, ミラーモデル先端は振幅が大きい振動をしており, これまでみてきた結果とほぼ同じ挙動を示していることがわかる. 特に, 測定点 $2 \sim 4$ は 1 に対して, 逆位相で振 動していることがわかる. model(a)と同様に, $V_{d}=0 \mathrm{~mm}$ を通過する際には，ストッパー側にある測定点 1 が他の測 定点より遅れてストッパーから離れていることがわかる．また，ストッパーに接触している間にも，測定点 1 は 振動しており，その振動の周期によって，ストッパーから離れる瞬間の挙動が変化していると思われる. すなわ ち, 測定点 $2,3,4$ が $V_{d}>0$ になる瞬間までに, 測定点 1 側が整数倍の周期で振動している場合には, $V_{d}=0$ を通 過する際に， $\theta$ の正の方向（上向き）に対して反対向きに運動する. このため，先端の振動は位相がずれ，スト ッパーから離れた後に逆位相の振動が起こり, 跳ね返り量が小さくなると考えられる. 一方, 図 12 (b) の跳承 返り量が大きくなった $y_{s}=20 \mathrm{~mm}$ と $y_{s}=36 \mathrm{~mm}$ では，跳ね返り後の振動は小さいことがわかる．また，測定点 1 と 測定点 $2 ， 3 ， 4$ とは同じ方向に同じタイミングで, $V_{d}=0$ を通過することから，ストッパーから離れた後の先端部 分での振動は小さくなっているようである.

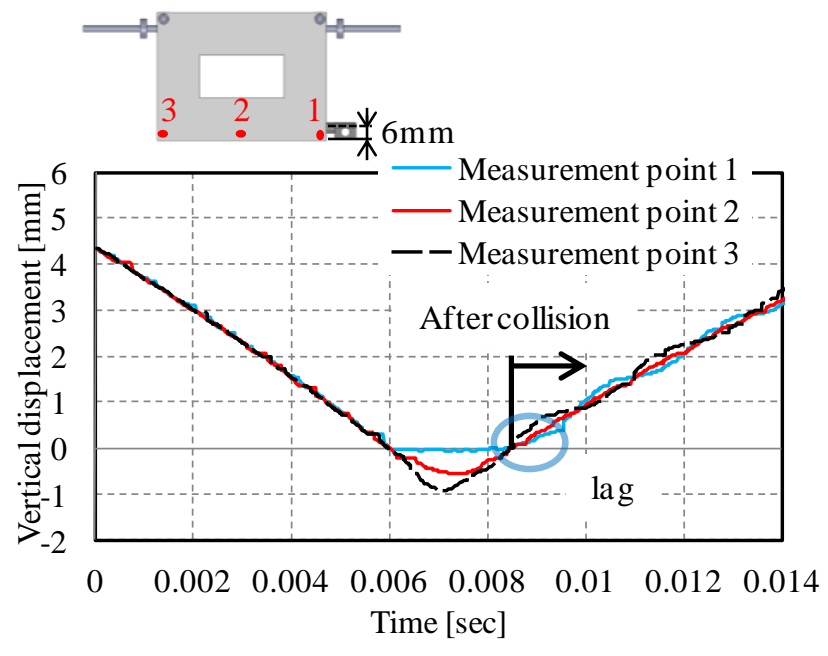

(a) Stopper position: $y_{s}=6 \mathrm{~mm}\left(\theta_{r}=25 \mathrm{deg}\right)$

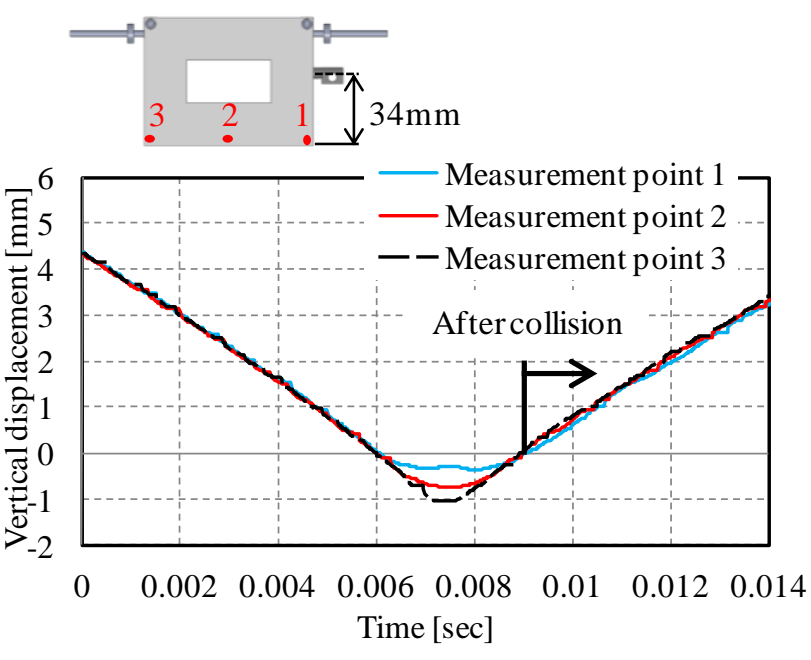

(b) Stopper position: $y_{s}=34 \mathrm{~mm}\left(\theta_{r}=32 \mathrm{deg}\right)$

Fig.11 Measurement result of the vibration behavior of Mirror model (b) 


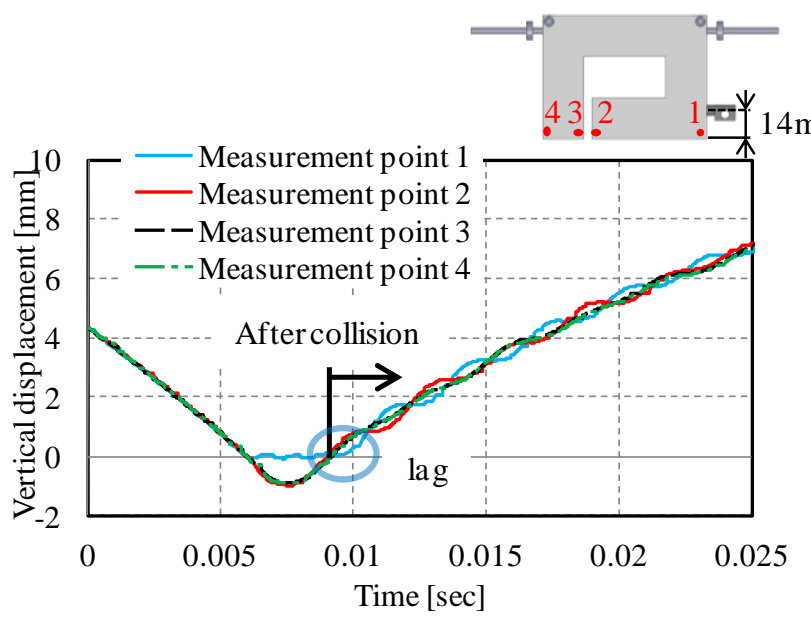

(a) Stopper position: $y_{s}=14 \mathrm{~mm}\left(\theta_{r}=24 \mathrm{deg}\right)$

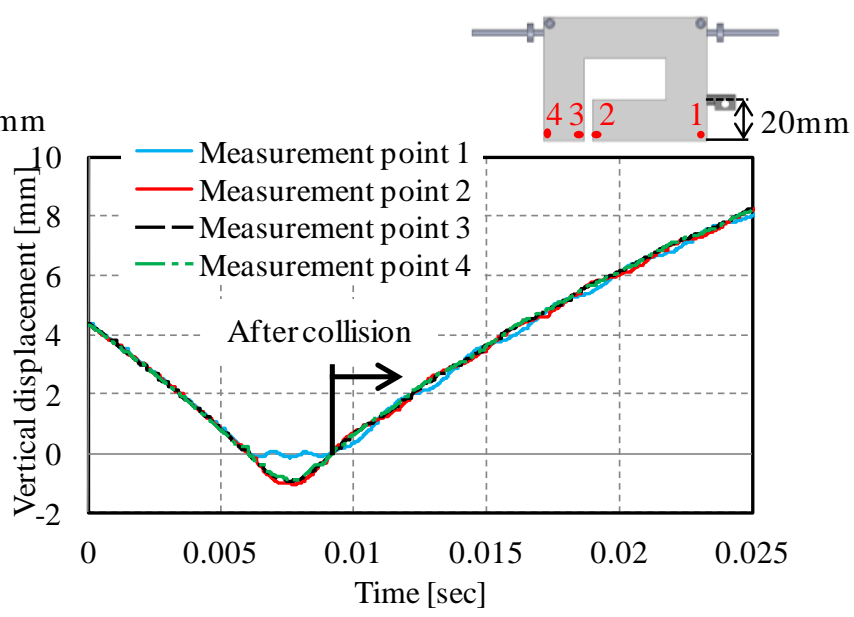

(b) Stopper position: $y_{s}=20 \mathrm{~mm}\left(\theta_{r}=30 \mathrm{deg}\right)$

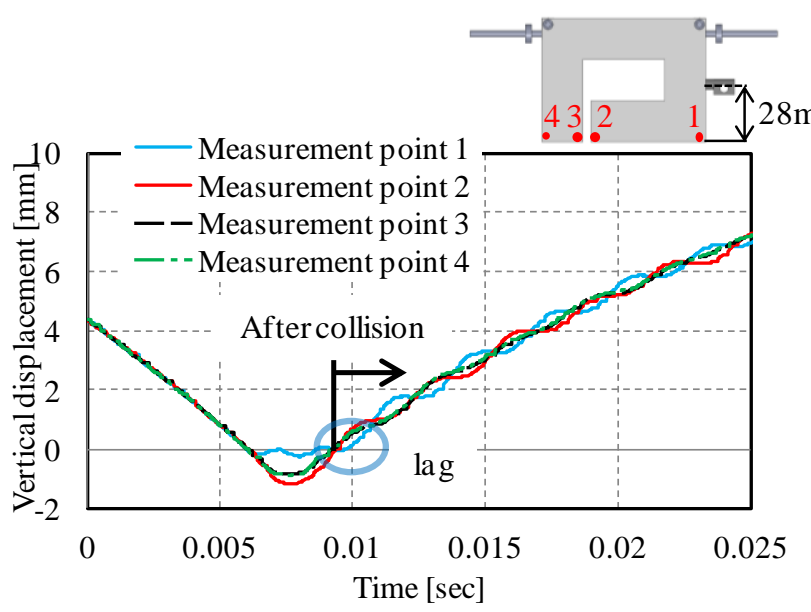

(c) Stopper position: $y_{s}=28 \mathrm{~mm}\left(\theta_{r}=26 \mathrm{deg}\right)$

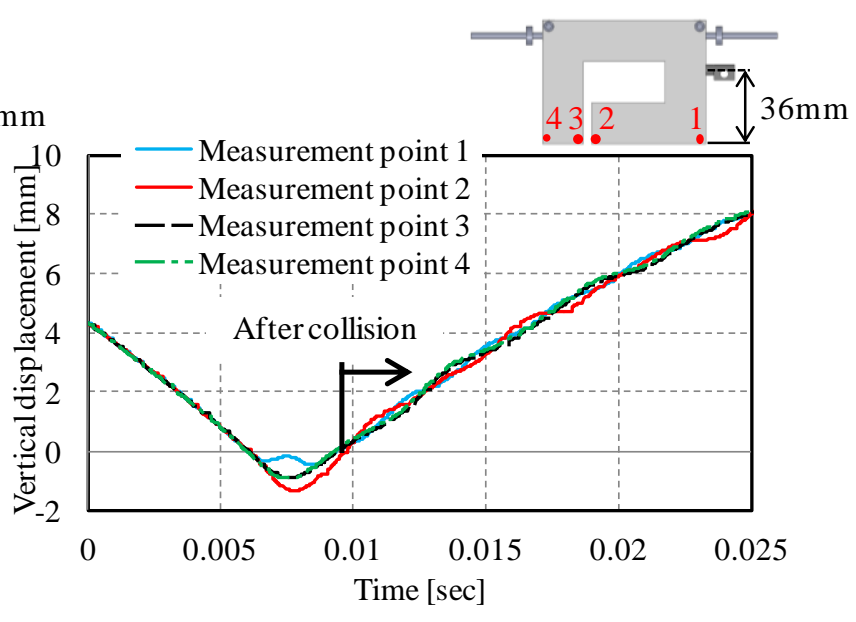

(d) Stopper position: $y_{s}=36 \mathrm{~mm}\left(\theta_{r}=31 \mathrm{deg}\right)$

Fig.12 Measurement result of the vibration behavior of Mirror model (c)

図 13 (a) 〜 (d) に $y_{s}=8 \mathrm{~mm}, 20 \mathrm{~mm} ， 28 \mathrm{~mm} ， 40 \mathrm{~mm}$ のときの Mirror model (d)の挙動測定結果を示す. 跳ね返 り量が小さくなった $y_{s}=8 \mathrm{~mm}$ と $y_{s}=28 \mathrm{~mm}$ では，跳ね返り後は振幅が大きい振動をしており，他のミラーモデルと ほぼ同じ挙動を示していることがわかる．また， $V_{d}=0 \mathrm{~mm}$ を通過する際には，ストッパー側にある測定点 1 ， 2 が 他の測定点より遅れてストッパーから離れていることがわかる. Mirror model(c)と比べて model(d)は，測定点 1 ， 2 がほぼ同じ動きをしており，さらに測定点 3,4 についても跳秋返り後の振動振幅が大きくなっていることがわ かる. このため，ミラーモデル全体で先端部が大きくねじれるような振動が起きていると考えられる. この振動 の励起によって, 跳ね返り量はかなり小さくなったと考えられる. 一方, 跳ね返り量が大きくなった $y_{s}=20 \mathrm{~mm}$ と $y_{s}=40 \mathrm{~mm}$ では，跳ね返り後はほとんど振動していないことがわかる.

図 14 (a), (b) に $y_{s}=6 \mathrm{~mm}$ と $y_{s}=42 \mathrm{~mm}$ のときの Mirror model (e)の挙動測定結果を示す.いずれの図においても, 測定点 3, 4 の挙動はほぼ同じ動きをしており, スリット側の部分は片持ち梁の横振動のような挙動となっている ことが予想できる．図 14 （a）の跳ね返り量が小さい場合をみると，計測点 $2 ， 3 ， 4$ は一度 $V_{d}<0$ となり，ほぼ同 時に $V_{d}=0$ を通過する. その間, 測定点 1 はほとんど動いていないが，他の計測点よりも遅れて $V_{d}>0$ の方に動き 始めることがわかる．その結果，計測点 $3 ， 4$ 側と逆位相の振動が生じていることがわかる. このミラーモデルは 他のミラーモデルよりも跳ね返り角が小さいモデルだが，振動挙動には大きな違いは無く，他の比較的跳ね返り 角が小さかったモデルと同様に先端側がねじれるような振動が生じている。このことから，跳ね返り角の大きさ を決める要素として，衝突時の振動挙動だけではなく，振動により生じる運動量や振動エネルギの影響も考慮す る必要があると考えられる。一方，図 14(b)のように，跳ね返り量が大きい場合には，測定点 $3 ， 4$ の跳ね返り後 の振動振幅は小さくなり， $y_{s}=42 \mathrm{~mm}$ ではほとんど振動しないことがわかる. 


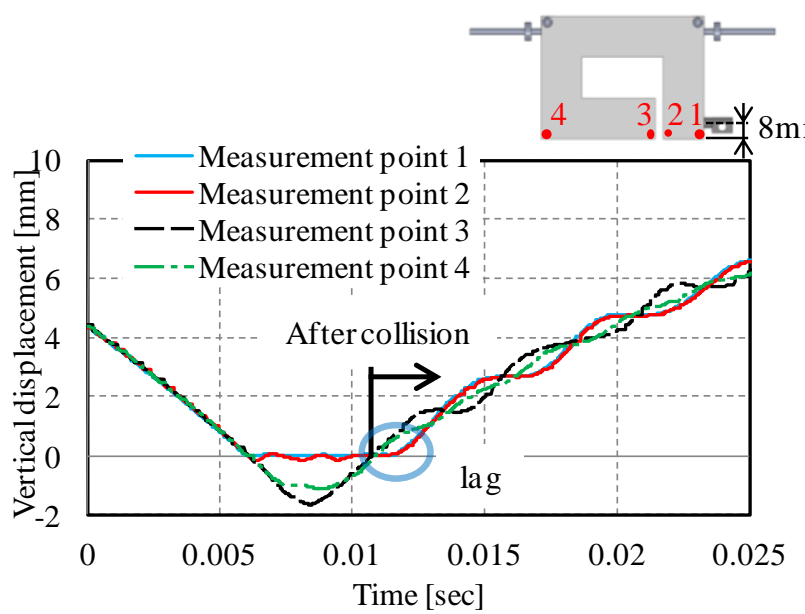

(a) Stopper position: $y_{s}=8 \mathrm{~mm}\left(\theta_{r}=24 \mathrm{deg}\right)$

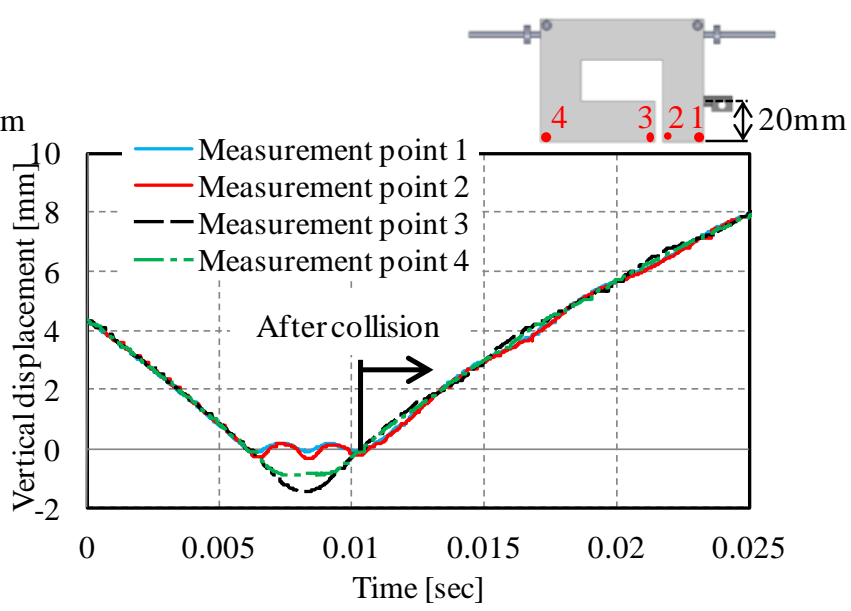

(b) Stopper position: $y_{s}=20 \mathrm{~mm}\left(\theta_{r}=30 \mathrm{deg}\right)$

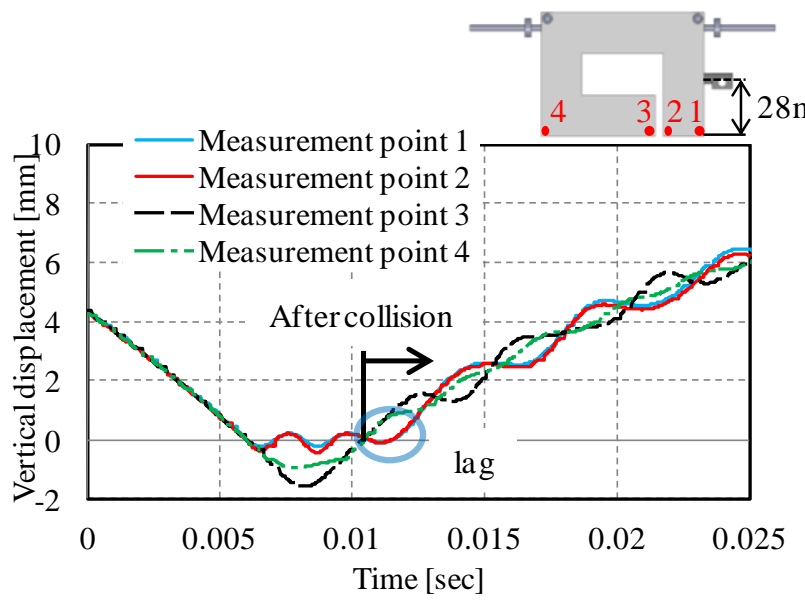

(c) Stopper position: $y_{s}=28 \mathrm{~mm}\left(\theta_{r}=21 \mathrm{deg}\right)$

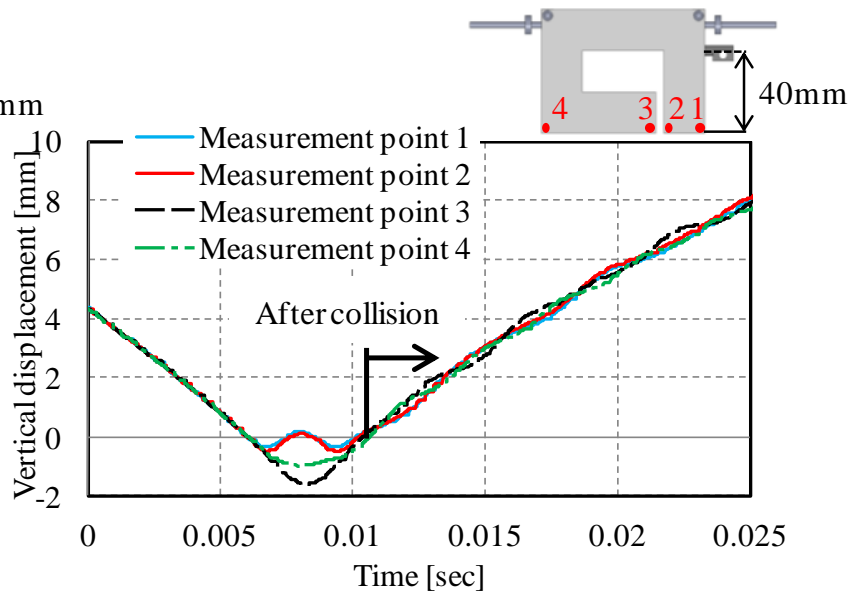

(d) Stopper position: $y_{s}=40 \mathrm{~mm}\left(\theta_{r}=33 \mathrm{deg}\right)$

Fig.13 Measurement result of the vibration behavior of Mirror model (d)

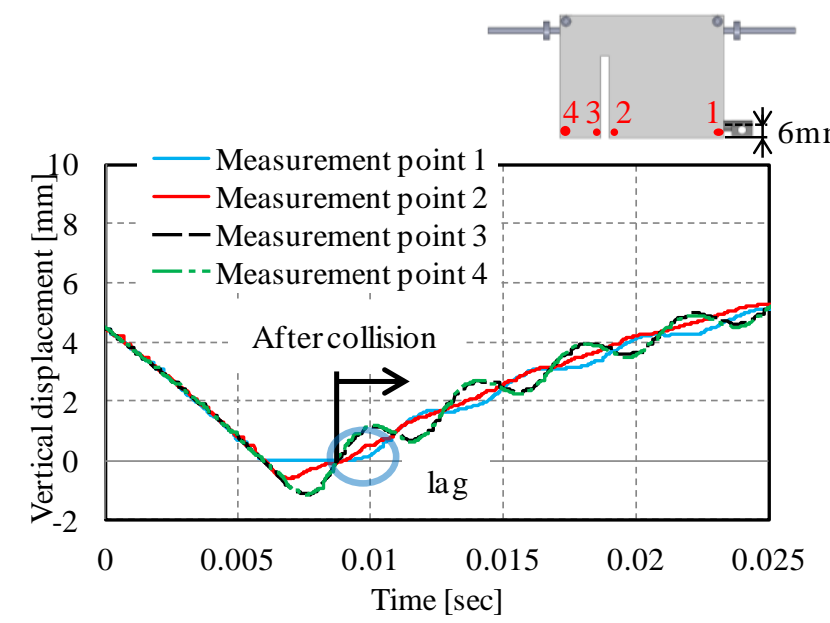

(a) Stopper position: $y_{s}=6 \mathrm{~mm}\left(\theta_{r}=12 \mathrm{deg}\right)$

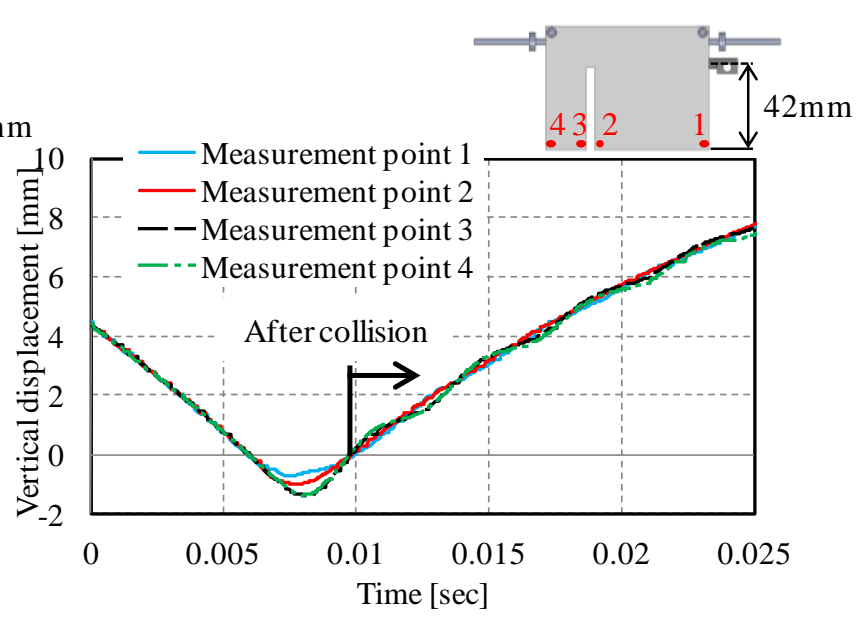

(b) Stopper position: $y_{s}=42 \mathrm{~mm}\left(\theta_{r}=28 \mathrm{deg}\right)$

Fig.14 Measurement result of the vibration behavior of Mirror model (e) 
図 15 (a)，（b）に $y_{s}=26 \mathrm{~mm}$ と $y_{s}=34 \mathrm{~mm}$ のときの Mirror model (f)の測定結果を示す. 図 15 (a)，(b)を比較する と，最小の跳ね返りを示した $y_{s}=26 \mathrm{~mm}$ のほうが跳ね返り後に大きな振動している様子がわかる．図 15 (a) をみ ると, 測定点 3，4 はほとんど振動していないのに対して, 測定点 $1 ， 2$ がほぼ同じ挙動で振動している様子がわ かる. さらに, 測定点 3,4 が $V_{d}=0$ を通過する際には, 測定点 1,2 が遅れた挙動を示していることがわかる. こ うした挙動は，model(d)の図 14 (a) と逆になっていることがわかる. 最大の跳ね返りを示した $y_{s}=34 \mathrm{~mm}$ では跳 ね返り後ほとんど振動していないことがわかる．このことから，曲げ岡性の低い部分が，タイミング良く大きく 振動することで，ミラーモデルの跳㸚返りを抑制していると考えられる.

全てのミラーモデルを比較すると, 衝突後, 振幅が大きな振動をすると跳ね返り量が小さくなり, 逆に振幅が 小さい振動をすると跳ね返り量が大きくなる傾向があることが明らかとなった．また，このときの振動はミラー 両端（Mirror model (a)， (b)は測定点 1 と 3, Mirror model (c) （f)は測定点 1 と 4) で逆位相の振動をする傾向があ る. 衝突の瞬間の挙動の計測結果から, $V_{d}=0 \mathrm{~mm}$ 近辺で, 寸なわち, ストッパーからミラーモデルが離れる際に, ストッパー側にある測定点 1 は他の測定点よりも遅れて離れる場合に, 跳ね返り量が小さくなる傾向があること が明らかになった。この遅れは，衝突してストッパーに接触している間の振動挙動に関連があると思われ，接触 中に現れる振動モードと固有振動数によって特徵づけられると考えられる.この遅れによってミラー両端で逆位 相の振動を生じさせ，さらに，遅れが大きくなることによって跳ね返り後の振幅を大きくなると考えられる.

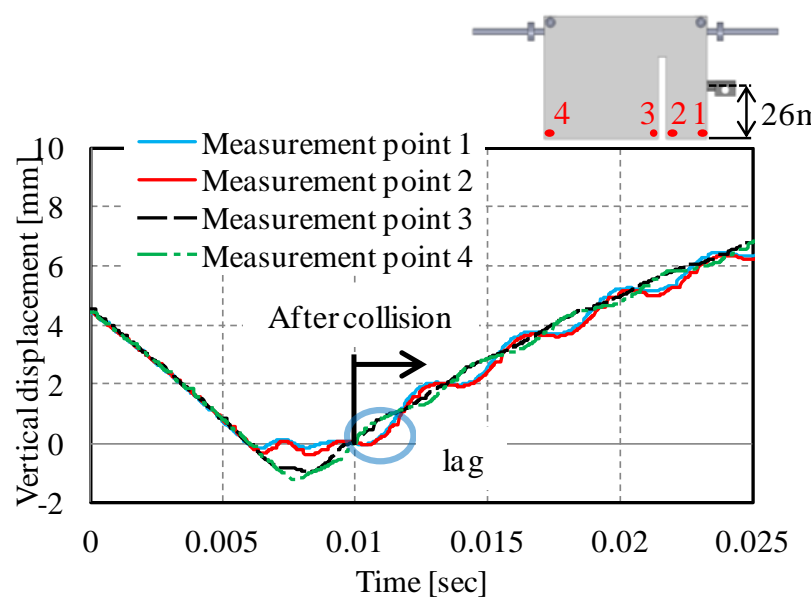

(a) Stopper position: $y_{s}=26 \mathrm{~mm}\left(\theta_{r}=23 \mathrm{deg}\right)$

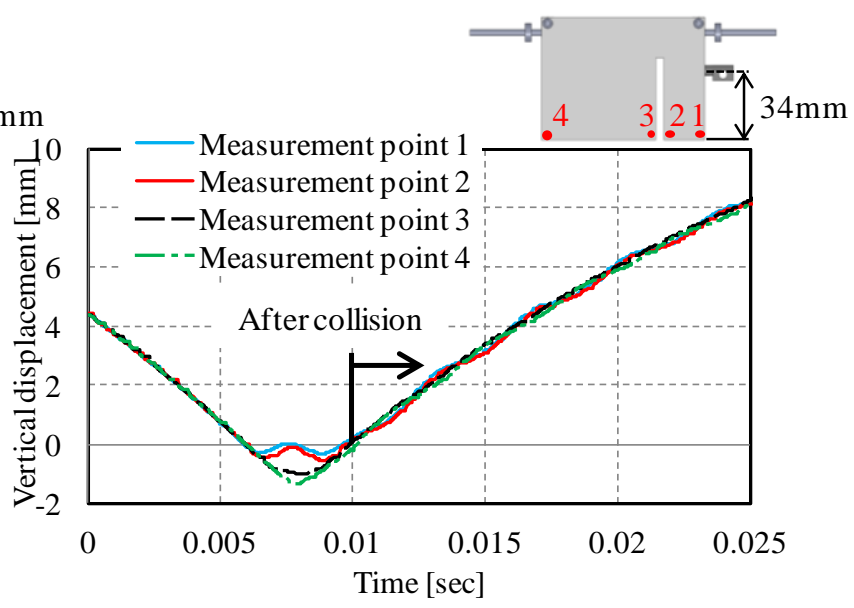

(b) Stopper position: $y_{s}=34 \mathrm{~mm}\left(\theta_{r}=32 \mathrm{deg}\right)$

Fig.15 Measurement result of the vibration behavior of Mirror model (f)

\section{4. 結言}

本研究では，回転支持された長方形平板の衝突時挙動と跳ね返り量について検証した．さらに，衝突時挙動と 跳ね返り量との関連を明らかにするために形状を変更したモデルを用いて実験した結果を以下にまとめる.

（1）跳返り量はストッパー位置に依存して変化する．ミラーモデルのうち長方形平板（Mirror model (a)） で跳ね返り量が最小になるストッパーの位置は先端から $8 \mathrm{~mm}$ であり, 跳ね返り量の最大と最小との差 は 6deg 程度となった。この結果は，中心に穴のある形状のモデル（Mirror model (b)）もほぼ同じ特性 となっている.また, スリットを有する形状の場合には, ストッパー位置が跳ね返り量に及ぼす影響は, より大きくなり, 跳悋返り量の最大と最小の差は 8 16deg 程度まで拡大寸る. また, 最小の跳ね返り 量を示したモデルはスリットがストッパーと反対側にある Mirror model (e)の場合で, 長方形板の Mirror model (a)に対して約半分になる場合も見られた.

(2) 跳ね返り量にはストッパーとミラーモデルが離れる瞬間のミラーモデル先端両端での振動挙動の影響 が反映されることが明らかになった. すなわち，跳ね返る瞬間において両端の挙動に位相のずれがある 場合, 跳ね返り後はミラーモデル先端が逆位相の振動をする.このような挙動の際に跳ね返り量が小さ くなる傾向があることが確認された。 
（3） スリットを有するモデルを用いた実験においても，跳ね返り量が小さいときには，Mirror model (a) と同 様に, 跳ね返り後のモデル先端の振動が大きくなることが確認され, 形状の変更によって, より明確に なり，ミラーモデル先端の挙動と跳ね返り量との関係は一致することが確かめられた.

\section{文献}

(1) 川副嘉彦, “衝突現象を考慮したテニスラケットの CAE(ボールと衝突におけるラケットの応答予測と反発性能の 評価指針)”，日本機械学会論文集 C 編，Vol. 58，No．552(1992)，pp. 143-150.

(2) 川副嘉彦, “ボール・ストリングス系の非線形性とフレーム振動モードを考慮したテニスラケットの反発係数分布 の解析”, 日本機械学会論文集 C 編, Vol. 59, No. 562(1993), pp. 76-83.

(3) 山口哲男, 山本卓也, 角田昌也, 岩壼卓三, “テニスラケットの最適設計に関する研究”, 日本機械学会論文集 C 編, Vol. 61, No. 588(1995), pp. 197-202.

(4) 川副嘉彦, 友末亮三, “テニスのインパクトにおけるラケットのスイートエリアの予測(反発係数, 反発力, ボール の飛び)”，日本機械学会論文集 C 編，Vol. 64，No. 623(1998)，pp. 72-78.

(5) 川副嘉彦, “テニスラケットのエネルギ損失と反発係数におよぼすフレーム面内フープ振動の影響”, 日本機械学会 ジョイント・シンポジウム 2006 (スポーツ工学シンポジウム / シンポジウム : ヒューマン・ダイナミクス) 講演論 文集，No. 06-35，(2006)，pp. 130-135.

（6）秦秀敏，宇津野秀夫，松久寛，“ボールの反撥を考慮した金属バットの振動モード解析”，日本機械学会ジョイント・ シンポジウム 2004 (スポーツ工学シンポジウム / シンポジウム : ヒューマン・ダイナミクス) 講演論文集, No. 04-26, (2004), pp. 89-94.

（7）松本大樹, 佐々木隆幸, 齊當建一, “回転支持平板の衝突跳ね上がり運動”, 日本機械学会 Dynamics \& Design Conference 2011 CD-ROM 論文集，(2011)，No.424. 